\title{
Role of Biofertilizer or Biopesticide in Agriculture Development and Novel Nano Bioformulation for Sustainable Agriculture
}

\author{
R. Jagadesh
}

10.18805/ag.D-5281

\begin{abstract}
Background: The purpose of this research is to find out the awareness and the acceptance of the bio fertilizer in and around the Niligiri district. The survey has been conducted to identify the awareness among the farmer's. Though, they are aware that, bio fertilizer will give more field than the chemical fertilizer farmers are unaware due to the low availability, high cost, initial low productivity. Since, bio fertilizers have significant and enduring environmental import, which nullifying the adverse effect of chemical fertilizer. The massive increase in the use of chemical fertilisers indicates that we are depleting our natural resources knowingly. This motivated the study to find out the awareness and acceptance of bio-fertilizers among the Tamil Nadu farmers and to find the ways and means of providing awareness to the farmers about the bio-fertilizers in order to increase their yield. The Niligiri district comprises of five taluk mainly Udhagamandalam, Kundah, coonoor, Kotagiri, Gudalur. The survey was carried out in and around of Kotagiri to Coonoor. The soil of Kotagiri and Kundah are more acidic in the nature. Organic carbon is high in all the type of soil. The available nitrogen content of the soil ranged between medium to high in all soil type. The phosphate availability is low due to the fixation of phosphate ion. The potassium content is high in all the type of soil. The ph plays major role in the soil type. The acidic soil might have lyst to open up and produce the juvnile. It is important to increase the soil fertility and better field non-organic fertilizer contains phosphate, ammonium etc. This could cause adverse effect in health as well as environmental problem.

Methods: It is an field investigation in 2020, the land are selected for the different resonance ranging from alluvial soil to the acidic soil. The study took place in and around the niligiri district, the fertilizers were localized for the geographical condition the soils were assessed for the use of fertilizer and their need of resonance.

Conclusion: The use of the chemical fertilizers has damaged the soil resonance. The chemical fertilizer has caused serious life threatening problem in the human being. This measure can be solved by the usage of bio fertilizer on the soil. The lack of awareness among the farmers is the major crises that is developing. The measure can be solved by creating awareness among the farmers by cultural practice of use of bio fertilizer in their field.
\end{abstract}

Key words: Agricultural practices, Biofertilizer, Entamopathogenic nematode, Environmental factor, Pesticide.

\section{INTRODUCTION}

Biopesticide are classified into three different categories they are plant-incorporated protectants, microbial pesticides, and biochemical pesticides they do not have any residue problem, which is a matter of substantial concern for consumers specifically for edible fruits and vegetables. By combining synthetic pesticide performance and environmental safety, biopesticides execute efficaciously with the tractability of minimum application limitations and with superior resistance management potential.Several research regulation has resolved rhizobacteria as growth regulator that increases the fertilizer efficicacy (Adesemoye and Kloepper (2009). Beginning in the 1980s and continuing to the present, a different molecular approach has been employed to develop market acceptance of biopesticides (Venkatashwarlu (2008). Bacillus thuringiensis was first discovered to have increased toxicity. These include B. thuringiensis ssp. kurstaki and aizawai, with the highest activity against lepidopteron larval species; $B$. thuringiensisisraelensis, with activity against mosquito larvae, black fly (simuliid) and fungus gnats. Toxicity of BTI and some other toxic strains is commonly imputed to the parasporal inclusion bodies ( $\delta$-endotoxins) which are
Kongunadu Arts and Science College (Autonomous) Gn Mills, Coimbatore-641 029, Tamil Nadu, India.

Corresponding Author: R. Jagadesh, Kongunadu Arts and Science College (Autonomous) Gn Mills, Coimbatore-641 029, Tamil Nadu, India. Email: jagasmartz11@gmail.com

How to cite this article: Jagadesh, R. (2021). Role of Biofertilizer or Biopesticide in Agriculture Development and Novel Nano Bioformulation for Sustainable Agriculture. Indian Journal of Animal Research. DOI: 10.18805/ag.D-5281.

Submitted: 02-12-2020 Accepted: 17-05 $2021 \quad$ Online: 31-07-2021

produced during sporulation time. (Dixon, (2000). These endotoxins must be assimilated by the larvae to accomplish toxicity. Bt and their subspecies produce different insecticidal crystal proteins ( $\delta$-endotoxins) and their toxicity was determined (Arun 2007). These toxins, when ingested by the larvae, can damage the gut tissues, leading to gut paralysis.

\section{MATERIALS AND METHODS}

The field study was conducted at farmers land in and around the nilgiris district to find out nutritional content and the problem encountered in different area of the nilgiris. The 
study was carried out during the period of May 2018 to Feb2019 in the Department of the Biotechnology at kongunadu Arts and Science. The soil sample were collected and assessed. The land altitude situated at is almost near 600 meter above the sea level. during the cropping season is $700 \mathrm{~mm}$ during the month of September to November. Thesoil contained low organic carbon (0.30), low available nitrogen (120.1) and $\mathrm{zn}(0.5)$ the available phosphorus content (156.2). The field study took place in a randomized manner and each soil attributes were assessed for the use of the fertilizer and the resonance of the fertilizer were assessed in the tea plantation for their growth. The growth of the tea plantation is based on the usage of urea ,though urea relatively causes serious problem in the field of agriculture and the status of their growth. The leaves of the plantation vary in colour changing from green to yellow and this measure of change was due to the effect of the chemical fertilizer on the field. The continuous use of sulphur (18.7) and the magnesium (13.4) has damaged the crop resonance and also the state of the soil. The resonance in the variation of nutritional factor observed in the vegetable, the continuous use of harmful pesticide has resolved serious problem in the human being. Ranging from the nutritional disease to the cancer. This measure can be avoided by the use bio fertilizer.

\section{RESULTS AND DISCUSSION \\ Regulation encountered in tea plantation}

Earlier, TRA recommended different pesticides [endosulfan, quinalphos, phosphamidon, phosalone, acephate, dimethoate, chlorpyrifos, monocrotophos, oxydemeton methyl, $\lambda$-cyhalothrin, $\beta$-cyfluthrin, ethofenprox, cartap hydrochloride, alphamethrin, cypermethrin, deltamethrin, profenophos, thiomethoxam, imidacloprid, dicofol, ethion, propargite, fenazaquin, sulfur and neem formulations] for controlling tea pests (Bakhetia and Sekhon, (1989). During the last several decades, the control of pests, diseases and weeds in tea fields is predominantly by the use of synthetic chemicals. It has harmful effects on human health and environment and presence of undesirable residue. The effective control of pests on tea is essential to ensure the marketability of this crop. However, despite the low consumption of pesticides, India has more problem of pesticide residue than other countries and these have entered into food products and underground water because of the non-prescribed pesticide use, inappropriate advice and supply of pesticides to planters, no nobservance of prescribed waiting period, use of sub-standard pesticides, effluents from pesticide manufacturing units, continued use of persistent pesticides for public health programmes. Chemical fertilizer has played a major role in the tea plantation from the time of growth to the harvest of tea leaf, chemical fertilizer are majorly used. It is frequently used because it enhanced rapid growth of the tea plantation. The commonly used chemical fertilizer ammonium sulphate, magnesium sulphate, potassium etc. The commonly used ammonium sulphate constitutes nitrogen $20.6 \%$, sulphate $23 \%$. It is most commonly used it enriches the soil and thereby increasing the growth of the plantation and several bacteria plays a major role in nitrogen fixation. (Wani and Lee 2006). The use of chemical fertilizer harms the soil and the use of ammonium sulphate in a frequent manner catalyses the brown leaf of the tea plantation due to the lack of magnesium in the plantation. The problem can be over resourced by the use of bio fertilizer phosphorous solubilising bacteria; vesicular abscularmycorvhiza could be loaded or broad spectrum bio fertilizer (Byrappa et al., (2012). Integrated pest management (IPM) is an ecosystem-based strategy that focuses on long-term prevention of pests or their damage through a combination of techniques such as biological control, habitat manipulation, modification of cultural practices, and use of resistant varieties. Pest control materials are selected and applied in a manner that minimizes risks to human health, beneficial and non-target organisms and the environment. Pest prone sections will be kept free from weeds and alternate host plants. For tea mosquito bug control, thinning out the shade trees in heavy shaded areas, removal of all the infested shoots to check the population, follow hard plucking or level of skiff in heavily infested section and during cold weather practices.

\section{Regulation encountered in vegetable}

Vegetables are rich in vitamins and minerals. They also contain antioxidants, such as beta-carotene and vitamin C; they also contain fiber. This can help to control cholesterol levels and keep blood sugar levels steady. Many studies encourage eating at least five portions of fruit and vegetables each day Regular monitoring of residue levels in fruits and vegetables is so required to keep these products safe. Definitions According to FAO, For humans, apart from occupational exposure, exposure to pesticides is indirect from food, and drinking water. Multiple routes of exposure to pesticides can be encountered in humans; occupational exposure is mainly for people handling the products. Farmers are a particularly exposed population; in agriculture, the exposure is mainly cutaneous and rarely oral; the absorption of pesticides by the skin is revealed as the most significant route. One study showed that wearing a protective suit did not completely prevent operator skin contamination with dithiocarbamate fungicides. In several epidemiological studies, there has been a significant association of pesticide

Table 1: Total area of land.

\begin{tabular}{lcc}
\hline Land & Accept & Not Accept \\
\hline $1 / 2$ acre & $55 \%$ & $45 \%$ \\
$2 / 3$ acre & $40 \%$ & $60 \%$ \\
Less than 5 & $20 \%$ & $80 \%$ \\
\hline
\end{tabular}

Table 2: Awareness and acceptance of bio-fertilizer.

\begin{tabular}{lcc}
\hline Awareness & Accept & Not accept \\
Aware & $40 \%$ & $60 \%$ \\
Unaware & $50 \%$ & $70 \%$ \\
\hline
\end{tabular}


Table 3: Pesticide residue in vegetable.

\begin{tabular}{|c|c|c|}
\hline Crop & Authorized Pesticides & Diseases or pests \\
\hline Potatoes & $\begin{array}{l}\text { Acaricide insecticides: alphamethrin, carbosulfan, } \\
\text { ethoprophos, betacyfluthrin, Cypermethrin, } \\
\text { deltamethrin, endosulfanEsfenvalerate, lambda } \\
\text {-cyhalothrin, Phosalone, pyrimicab, azinphos } \\
\text {-methylTefluthrin, malathion }\end{array}$ & $\begin{array}{l}\text { Wireworms, Colorado potato } \\
\text { beetle, aphids, moths }\end{array}$ \\
\hline Carrot & $\begin{array}{l}\text { Acaricide insecticides: benturacarb, Carbofurane, } \\
\text { chlorfenvinphos, Diethion, endosulfan, lambda- } \\
\text { ccyhalothrin, pirimicrab, rotenon } \\
\text { Taufluvaliant }\end{array}$ & Fly, aphids \\
\hline Onion & $\begin{array}{l}\text { Acaricide insecticides: Carbofuran, chlorfenvinphos, } \\
\text { lambda-cyhalothrin, azinphosmethyl,cyfluthrin, } \\
\text { deltamethrin }\end{array}$ & Fly, ringworm, thrips \\
\hline Cucumber & $\begin{array}{l}\text { Acaricideinsecticides: abamectin, Acrinathrin, } \\
\text { clofentzine, fenazaquin, Fenbutatinoxide, } \\
\text { hexythiazox, Deltamethrin, methomyl,pymetrozine, } \\
\text { Pyriproxyfen, cyromazineAlphamethrin, esfenvalerate, } \\
\text { lambda-Cyhalothrin, pirimicrab,endosulfan, Rotenone }\end{array}$ & $\begin{array}{l}\text { Alternaria, anthracnose } \\
\text { mildew, powderymildew, rot }\end{array}$ \\
\hline Tomatoes & $\begin{array}{l}\text { Acaricideinsecticides: alphamethrin,Bifenthrin, } \\
\text { deltamethrin, abameetin, Acrinathrin, cyhexatin, dielofop, } \\
\text { Fenazaquin, fenbutatinoxide, Hexythiazox, sulphur, } \\
\text { buprofezin, Methomly, pymetrozine, pyriproxyfen, } \\
\text { Carbaryl, lambda-cyhalothrin,rotenone, Cyrornazine, } \\
\text { indoxacrab, pirimicrab, Tau-fluvalinate, formetanate }\end{array}$ & $\begin{array}{l}\text { Mites, fleabeetle, whiteflies, } \\
\text { Leafhoopers, leafminer, Colorado, } \\
\text { potato beetle, Thrips aphids }\end{array}$ \\
\hline Beansz & $\begin{array}{l}\text { Acaricideinsecticides: bifenthrin, Diclofop, fenbutatinoxide, } \\
\text { hexythiazox, Benfuracrab, chlorpyrifos, carbonfuran, } \\
\text { Deltamethrin, pirimicrab, lambda-Cyhalothrin, alphamethrin }\end{array}$ & Mites, fly, aphids, boter \\
\hline
\end{tabular}

(Khedkar et al., (2012). This lead to the occurrence of certain types of cancer such as cancers of the lips, prostate, stomach, kidneys, brain, but also most cancers of the hematopoietic system (leukemia, multiple myeloma and especially non-Hodgkin's lymphoma), cutaneous melanoma. On other occasion it may be due to the mechanical damage and abnormal environmental diseases onion root pink disease picked up primarily in the onion pathogen and it can go up to depth (1.5ft) deep. Early light of potato is a common disease in the potato farming site. The disease primarily affects the leaves and item under the favourable weather condition. The same relevance occour on the tomato where the leaf spot ate "bull eye" and the development of the patterned leaf spots are absorbed. This relevance can be avoided by the usage of bio fertilizer as it regards the resistance against the bacterial and the fungal disease on the vegetable. The use of chemical fertilizer has been effective but if regulates serious health problem in when consumed and affects the soil resources. Some common diseases include. Fire Blight (Bacillus arnylovorus) the most striking characteristics of fire blight are the browning of leaves and blackening of twigs (Dhaliwal, et al., (2010). Fire blight is so called because in severe cases whole part may appear to have been scorched. The disease is caused by a bacterium and is very contagious. Usually the microbe is carried to the tree by insects which visit the flowers or twigs. When it is deposited on a flower it multiplies very rapidly and the blossom is blackened and killed. This phase of the disease is known as blossom blight. The infection may extend along under the bark, killing and blackening the twig and often progressing into the branches. It may also get into the trunk, either through wounds or through shoots growing out from the trunk and may then cause the so-called body blight. When it gets into the base of the root it may cause what is known as collar rot or collar blight. This selected and treated seed should be planted on soil which has not grown beans for several years. If the disease appears, the vines should not be cultivated when they are wet, since this may infect other plant. Blight (Pseudomonas phaseoli ) all of the above-ground parts are susceptible to blight. The disease is very noticeable on the leaves, where it may form large water soaked areas which later become thin and papery. All of the leaves may sometimes be very seriously affected. Downy Mildew, Downy mildew is usually not serious in Minnesota. It attacks the pods and leaves and sometimes the stems. 


\section{Entomopathogenic nematode in pest control}

Selection of an EPN for control of a particular pest insect is based on several factors that include the nematode's host range, host finding or foraging strategy, tolerance of environmental factors and their effects on survival and efficacy (temperature, moisture, soil type, exposure to ultraviolet light, salinity and organic content of soil, means of application, agrochemicals and others (Klein 1990). The 4 most critical factors are moisture, temperature, pathogenicity for the targeted insect. Within a favorable range of temperatures, adequate moisture and a susceptible host, those EPNs with a mobile foraging strategy (cruisers and intermediate foraging strategies) could be considered for use in subterranean and certain above-ground habitats foliar and cryptic habitats. (Singh et al., 2011). However, the fact will remain that other advancements are needed to strengthen the efficacy and the field host range beyond the current target insects, crops and environment (Wani and Lee (1995). examples: root maggots, flea beetles, corn rootworms, cucumber beetles and wireworms) Entomopathogenic nematode are soil inhabiting, lethal insects parasite that baling to the phylum nematode and they are proven to be most effective as biological control organism.

\section{CONCLUSION}

\section{Awareness and acceptance of bio-fertilizer}

The research has been limited to the small attributes of only village from kotagiri to Connor. The data is collected from various field $55 \%$ of the farmer are above 52 years of age and are influenced by zamin of the village. The bio fertilizer can be promoted and can be retailed $55 \%$ of the farmers have more than 5 years of land. Nearly $40 \%$ of farmers are aware of bio fertilizer and ready to accept the resonance instead of chemical fertilizer nearly $60 \%$ of the farmer are satisfied with the chemical fertilizer and can be insisted to use the bio fertilizer $50 \%$ of the farmers are aware of the usage of the bio fertilizer. They can be educated to sustain high field and bio fertilizer eco-friendly most of the village for the distribution of the bio fertilizer $90 \%$ of farmers are not using bio fertilizer because of its limited availability It can be made available through the local retailer shop most of the farmers are aware of the bio fertilizer It's activity can be increased by the promotional activity most of the farmers constitute large area of the land.

The farmers having the less area of the land are ready to accept the usage of the bio fertilizer. The farmers of land 3 to 5 area are not ready to accept the bio fertilizer as they are unaware of the usage of bio fertilizer and they area reliably happy with the use of the chemical fertilizer. The farmer inclines that the use of bio fertilizer may sustain less profit and mid awareness. Through the case study we were able to know about the various importances of the agriculture and the problems faced by the farmers in the agriculture field. This study is able to determine about the acceptance of bio fertilizer in the niligiri district. The main sustainable wealth pro claim or because of low yield, high out, less availability. The lack of awareness must be promoted among the farmer and various benefit of the usage of the bio fertilizer and thus does not have any harm to the soil.

\section{REFERENCES}

Adesemoye, A.O, Kloepper J.W. (2009). Plant-microbes interactions in enhanced fertilizer-use efficiency. Appl Microbiol Biotechnol. 85: 1-12.

Arun, K.S., (2007). Bio-fertilizers for sustainable agriculture. Mechanism of $\mathrm{P}$-solubilization Sixth edition, Agribios publishers, Jodhpur, India. 196-197.

Bakhetia, D.R.C. and Sekhon, B.S. (1989). Insect pests and their management rapeseed mustard. Journal of Oilseeds Research. 6(2): 269-273.

Byrappa, A.M., Kumar, N.G. and Divya, M. (2012). Impact of biopesticides application on pod borer complex in organically grown field bean ecosystem. Journal of Biopesticide. 5: 148-160.

Dhaliwal, G.S., Jindal, V. and Dhawan, A.K. (2010). Insect pest problems and yield losses: Changing trends. Indian Journal of Ecology. 37: 1-7.

Dixon, A.F.G. (2000). Insect predator-prey dynamics, In: Ladybird beetles and biological control. Cambridge Univ. Press. United Kingdom.

Khedkar, A.A., Bharpoda, T.M., Patel, M.G. and Patel, C.K. (2012). Efficacy of different chemical insecticides against mustard aphid, Lipaphis erysimi (Kaltenbach) infesting mustard. AGRES-An International e-Journal. 1(1): 53-6.

Klein, M.G. (1990). Efficacy against Soil-inhabiting Insectpests. In: Entomopathogenic Nematodes in Biological Control. [Gaugler R and Kaya HK (ed.)]. CRC, BocaRaton, Florida. pp. 195-214.

Singh, J.S., Pandey V.C., Singh D.P. (2011). Efficient soil microorganisms: a new dimension for sustainable agriculture and environmental development. Agriculture Ecosystem Environment. 140: 339-353.

Venkatashwarlu, B. (2008). Role of bio-fertilizers in organic farming: Organic farming in rain fed agriculture: Central institute for dry land agriculture, Hyderabad. 85-95.

Wani, S.P. and Lee K.K. (1995). Microorganisms as biological inputs for sustainable agriculture in Organic Agriculture (Thampan, P.K.ed.) Tea Crops Development Foundation, Cochin, India. 39-76.

Wani, S.P. and Lee K.K. (2006). Population dynamics of nitrogen fixing bacteria associated with pearl millet $(P$. americanum $L$.), In biotechnology of nitrogen fixation in the tropics, University of Pertanian, Malaysia. 21-30. 